\title{
Optimasi Heat Unit sebagai Kriteria Panen Pisang Barangan dari Lima Waktu Antesis
}

\author{
Heat Unit Optimization as Harvest Criteria on Banana "Barangan" \\ at Five Time Anthesis \\ Turi Handayani ${ }^{1}$, Winarso Drajad Widodo ${ }^{1 *}$, Ani Kurniawati ${ }^{1}$ dan Ketty Suketi ${ }^{1}$
}

Diterima 20 September 2019/Disetujui 05 Februari 2020

\begin{abstract}
Harvest time can affect the shelf life and quality of fruit during storage, therefore, the right method is needed in accordance with harvest time. This study aimed to optimize heat units as a harvest criteria of Barangan banana and its effect on fruit quality. The study was conducted at Sukabumi, West Java PTPN VIII in October 2018 to February 2019 using Randomized Complete Block Design with single factor and five anthesis time: anthesis 1 (October 13 ${ }^{\text {rd }} 2018$ ), anthesis 2 (October $20^{\text {th }}$ 2018), anthesis 3 (October 27th 2018), anthesis 4 (November 03 ${ }^{\text {rd }} 2018$ ), anthesis 5 (November 10 ${ }^{\text {th }}$ 2018). The results showed Barangan banana was harvested at a minimum heat unit of $1234.50 \pm 2.76$ ${ }^{0} \mathrm{C}$ degree days with a harvest time of 72-73 days and a shelf life of 16-17 days and can be used as harvesting criteria. Different time of anthesis did not affect to harvested fruit size, shelf life, weight loss, physical quality and chemical quality of fruit.
\end{abstract}

Keywords: fruit quality, maturity, shelf life, temperature, weight loss

\begin{abstract}
ABSTRAK
Waktu panen dapat berpengaruh terhadap umur simpan dan kualitas buah selama penyimpanan, sehingga dibutuhkan metode yang tepat dalam menentukan kriteria panen. Percobaan ni bertujuan untuk mengoptimasi akumulasi satuan panas sebagai kriteria panen pisang Barangan dan pengaruhnya terhadap kualitas buah. Percobaan dilakukan di PTPN VIII Parakan Salak, Sukabumi, Jawa Barat pada Oktober 2018 hingga Februari 2019 dengan menggunakan Rancangan Acak Kelompok (RAK) faktor tunggal dengan perlakuan lima waktu antesis. Antesis 1 (13 Oktober 2018), antesis 2 (20 Oktober 2018), antesis 3 (27 Oktober 2018), antesis 4 (3 November 2018) antesis 5 (10 November 2018). Hasil penelitian menunjukkan bahwa satuan panas $1234.50 \pm 2.76{ }^{\circ} \mathrm{C}$ hari dapat digunakan sebagai kriteria panen pisang Barangan dengan umur panen 72 -73 HSA dan umur simpan 16-17 hari. Waktu antesis tidak berpengaruh terhadap ukuran buah saat dipanen, umur simpan, susut bobot, kualitas fisik dan kualitas kimia buah.
\end{abstract}

Kata kunci: kualitas buah, kematangan, umur simpan, suhu, susut bobot

\section{PENDAHULUAN}

Pisang merupakan buah yang paling banyak diproduksi di Indonesia. Berdasarkan data BPS (2019) produksi buah pisang pada 2018 mencapai 7264383 ton. Buah pisang termasuk buah klimakterik yang ditandai dengan meningkatnya laju respirasi pada saat buah masak, dan hal ini berhubungan dengan meningkatnya laju produksi etilen. Murtadha et al. (2012) menyatakan bahwa bahan pemacu seperti gas etilen, etepon dan gas asetilen dapat memacu proses pemasakan pisang Barangan dan berperan dalam perubahan fisiologi dan kualitas kimia buah. 
Pisang Barangan memiliki 7-9 sisir per tandan dengan jumlah buah per sisir sebanyak 15-17 buah, bobot per buah berkisar 90-94 g. Kulit buah yang sudah masak berwarna kuning dengan bintik coklat, daging buah berwarna jingga, memiliki rasa manis dan harum, kadar gula $29.60{ }^{\circ}$ Brix, dan vitamin C $54.21 \mathrm{mg} 100$ $\mathrm{g}^{-1}$ (Kementan, 1995).

Tingkat kematangan buah saat dipanen menjadi faktor yang mempengaruhi kualitas fisik maupun kualitas kimia buah pisang. Penentuan kriteria panen pisang dapat dilakukan dengan beberapa metode. Penelitian Dzomeku et al. (2016) menentukan kematangan pisang Apantu (Tanduk lokal) dengan metode warna kulit buah dan umur panen. Buah yang dipanen muda ketika masak memiliki kualitas yang kurang baik dan jika dipanen terlalu tua daya simpan menjadi rendah. Rahayu et al. (2014) memaparkan pisang Raja Bulu yang dipetik tua lebih cepat mencapai kemasakan dibandingkan dengan buah yang dipetik muda. Umur buah masih banyak digunakan sebagai metode penentuan kematangan pisang. Metode umur buah ini memiliki kekurangan yaitu dapat menimbulkan keragaman dalam kualitas buah karena perbedaan tingkat kematangan fisiologi pisang.

Metode yang dapat digunakan untuk menentukan kriteria kematangan buah pisang adalah dengan akumulasi satuan panas (heat unit) dengan menghitung akumulasi suhu harian sejak antesis hingga panen. Meena $\mathrm{et} \mathrm{al}$. (2013) akumulasi satuan panas dapat digunakan sebagai metode dalam penentuan kriteria kematangan pada kacang tanah dengan memperhatikan beberapa aspek yaitu perbedaan suhu, intensitas cahaya antar lokasi dan perbedaan musim.

Pemantapan akumulasi satuan panas sebagai indikator untuk menentukan waktu panen pisang yang lebih tepat sehingga dapat diterapkan di berbagai lokasi dan waktu. Percobaan ini merupakan rangkaian percobaan atau kelanjutan dari percobaan yang telah dilakukan. Pisang Barangan dapat dipanen pada umur 78 HSA, akumulasi satuan panas (1 200$1250{ }^{\circ} \mathrm{C}$ hari) dengan umur simpan 13-14 hari (Widodo et al., 2019). Penelitian ini bertujuan untuk mengoptimasi metode akumulasi satuan panas (heat unit) sebagai kriteria panen pisang Barangan dan pengaruhnya terhadap kualitas buah terbaik dari berbagai waktu antesis.

\section{BAHAN DAN METODE}

Percobaan dilakukan di Perkebunan Parakansalak, PT Perkebunan Nusantara VIII Sukabumi, Jawa Barat pada Oktober 2018 sampai Februari 2019. Analisis kualitas fisik dan kualitas kimia buah dilakukan di Laboratorium Pascapanen, Departemen Agronomi dan Hortikultura, Fakultas Pertanian, Institut Pertanian Bogor. Analisis warna buah dilakukan di Laboratorium Pengemasan, Departemen Teknologi Industri Pertanian, Fakultas Teknologi Pertanian, Institut Pertanian Bogor dan analisis proksimat dilakukan di Pusat Penelitian Sumberdaya Hayati dan Bioteknologi, Institut Pertanian Bogor.

Percobaan menggunakan Rancangan Acak Kelompok (RAK) faktor tunggal dengan perlakuan 5 waktu antesis. Perlakuan waktu antesis terdiri dari antesis 1 dilakukan pada 13 Oktober 2018, antesis 2 (20 Oktober 2018), antesis 3 (27 Oktober 2018), antesis 4 (03 November 2018) dan antesis 5 (10 November 2018). Setiap perlakuan terdiri dari 5 ulangan tanaman pisang sehingga terdapat 25 satuan percobaan dan setiap tanaman mewakili satu satuan percobaan. Waktu antesis adalah waktu menandai bunga pada tanaman pisang Barangan.

Penandaan bunga dilakukan pada bunga yang siap antesis yaitu ditandai dengan bunga yang telah membuka sebanyak satu seludang. Penandaan dilakukan dengan menandai lima tanaman setiap minggunya sampai lima minggu dengan memperhatikan kondisi fisik tanaman. Tanaman pisang Barangan berasal dari anakan pertama dari induknya. Selama fase pengisian buah dari antesis hingga panen dilakukan perekaman suhu maksimum dan minimum setiap hari untuk menghitung jumlah satuan panas $\left({ }^{\circ} \mathrm{C}\right.$ hari) dan perekaman intensitas cahaya matahari (lux). Sampel buah yang digunakan untuk analisis kualitas buah adalah bagian tengah tandan yaitu pada sisir ketiga.

Pisang Barangan dipanen setelah mencapai satuan panas $1225^{\circ} \mathrm{C}$ hari mengacu pada penelitian Widodo et al. (2019). Buah pisang yang telah dipanen dihitung jumlah buah per sisir, bobot per sisir dan bobot per buah. Selama pemeraman dilakukan penghitungan laju respirasi dengan mengukur kadar $\mathrm{CO}_{2}$ yang dihasilkan buah pisang setelah melalui proses inkubasi selama tiga jam menggunakan alat 
cosmotector (Cosmos Cosmotector XP-316A Gas Detector). Analisis indeks skala warna pisang juga dilakukan selama pemeraman dimulai dari skala 1 (hijau) sampai skala 6 (kuning penuh/layak konsumsi). Pisang Barangan yang telah mencapai skala 6 digunakan untuk analisis kualitas fisik dan kualitas kimia buah. Analisis kualitas fisik buah meliputi umur simpan, susut bobot, kelunakan kulit dan daging buah, bagian dapat dimakan (BDD) dan kecerahan kulit dan daging buah. Kelunakan buah dihitung berdasarkan kelunakan kulit dan daging buah pada bagian pangkal, tengah dan ujung buah menggunakan penetrometer. Analisis kecerahan warna kulit dan daging buah menggunakan colorimeter dengan sistem penilaian warna: L* (lightning), $\mathrm{a}^{*}$ (redness) dan $\mathrm{b}^{*}$ (yellowness) mengacu pada penelitian Abdurrohim et al. (2018). Analisis kualitas kimia buah terdiri atas kandungan padatan terlarut total (PTT), asam tertitrasi total (ATT), vitamin $\mathrm{C}$ dan proksimat. Padatan terlarut total diukur dengan refraktormeter digital. Pengukuran asam tertitrasi total dan kandungan vitamin $\mathrm{C}$ menggunakan metode titrasi mengacu pada AOAC (1995). Analisis kandungan proksimat terdiri atas karbohidrat, protein, lemak, kadar air dan abu. Uji kadar air, abu dan lemak total menggunakan metode gravimetri, uji protein menggunakan metode Kjeldhal dan uji karbohidrat menggunakan metode by difference. Data hasil pengamatan dianalisis menggunakan software excelstat. Hasil yang berpengaruh nyata dilanjutkan dengan uji Beda Nyata Jujur (BNJ) pada taraf $5 \%$.

\section{HASIL DAN PEMBAHASAN}

Penandaan bunga pisang barangan antesis 1 dilakukan pada bulan Oktober yang merupakan awal musim penghujan. Hal ini ditandai dengan curah hujan yang diperoleh tanaman mulai dari penandaan bunga hingga panen sebanyak $1159 \mathrm{~mm}$ dan akumulasi satuan panas sebesar $1233.50{ }^{\circ} \mathrm{C}$ hari. Antesis 5 menunjukkan umur panen 72 hari dengan akumulasi satuan panas $1231.00{ }^{\circ} \mathrm{C}$ hari, satu hari lebih cepat dibandingkan waktu antesis lainnya yaitu 73 hari (Tabel 1). Pada antesis 5 tanaman mendapatkan intensitas cahaya matahari sejak awal antesis hingga panen sebesar 63669 lux dengan curah hujan $960 \mathrm{~mm}$ dan jumlah hari hujan 50 hari (Tabel 2).

Waktu antesis tidak berpengaruh terhadap ukuran buah saat dipanen (jumlah buah per sisir, bobot per sisir dan bobot per buah) (Tabel 1). Hal ini menunjukkan bahwa dengan jumlah satuan panas yang sama, perbedaan waktu antesis tidak mempengaruhi ukuran buah pisang Barangan.

Tabel 1. Akumulasi satuan panas, umur panen, jumlah buah per sisir, bobot per sisir dan bobot per buah pisang Barangan pada lima waktu antesis

\begin{tabular}{cccccc}
\hline $\begin{array}{c}\text { Waktu } \\
\text { Antesis }\end{array}$ & $\begin{array}{c}\text { Satuan Panas } \\
\left({ }^{0} \mathrm{C} \text { hari }\right)\end{array}$ & $\begin{array}{c}\text { Umur } \\
\text { Panen } \\
(\text { HSA })\end{array}$ & $\begin{array}{c}\text { Jumlah Buah per } \\
\text { Sisir } \\
(\text { buah })\end{array}$ & $\begin{array}{c}\text { Bobot } \\
\text { per Sisir } \\
(\mathrm{g})\end{array}$ & $\begin{array}{c}\text { Bobot } \\
\text { per Buah } \\
(\mathrm{g})\end{array}$ \\
\hline Antesis 1 & 1233.50 & 73 & 14.25 & 1055.13 & 70.51 \\
Antesis 2 & 1238.50 & 73 & 15.07 & 1361.04 & 73.52 \\
Antesis 3 & 1234.00 & 73 & 14.04 & 1204.17 & 71.75 \\
Antesis 4 & 1235.50 & 73 & 12.67 & 1279.08 & 71.61 \\
Antesis 5 & 1231.00 & 72 & 17.56 & 1011.10 & 69.99 \\
Rata-rata & $1234.50 \pm 2.76$ & & & & \\
\hline
\end{tabular}

Tabel 2. Jumlah hari hujan dan curah hujan bulan Oktober 2018 sampai Februari 2019

\begin{tabular}{lccc}
\hline Waktu Antesis & $\begin{array}{c}\text { Curah Hujan } \\
(\mathrm{mm})\end{array}$ & $\begin{array}{c}\text { Hari Hujan } \\
\text { (hari) }\end{array}$ & $\begin{array}{c}\text { Intesitas Cahaya Matahari } \\
\text { (lux) }\end{array}$ \\
\hline Antesis 1 & 1159 & 52 & 60164 \\
Antesis 2 & 1133 & 51 & 59443 \\
Antesis 3 & 1075 & 50 & 60139 \\
Antesis 4 & 1024 & 53 & 61820 \\
Antesis 5 & 960 & 50 & 63669 \\
\hline
\end{tabular}




\section{Laju Respirasi dan Umur Simpan}

Laju respirasi merupakan salah satu indikator yang berpengaruh terhadap umur simpan buah. Laju respirasi dan umur simpan diamati sejak proses pemanenan hingga buah mencapai tingkat kematangan terbaik (skala warna kulit 6). Selama proses pemeraman laju produksi gas $\mathrm{CO}_{2}$ buah pisang cenderung meningkat dan mencapai titik puncak kemudian menurun setelah proses pemasakan selesai atau kulit buah berwarna kuning penuh. Pada pisang Barangan puncak laju respirasi terjadi pada skala warna 5 dan terjadi penurunan pada skala 6 (Gambar 1). Hal ini sejalan dengan Kheng et al. (2011) pisang Rastali termasuk buah klimakterik mengalami produksi $\mathrm{CO}_{2}$ dan etilen meningkat selama pemasakan dan menurun ketika buah memasuki tahap penuaan.

Umur simpan merupakan salah satu faktor yang menentukan kualitas buah terjaga dengan baik hingga ke tangan konsumen. Hasil analisis umur simpan menunjukkan bahwa waktu antesis yang berbeda tidak berpengaruh mempengaruhi umur simpan yaitu 16-17 hari. Hal ini menunjukkan bahwa umur simpan pisang barangan tidak dipengaruhi oleh perbedaan waktu antesis, jika dipanen pada akumulasi satuan panas yang sama.

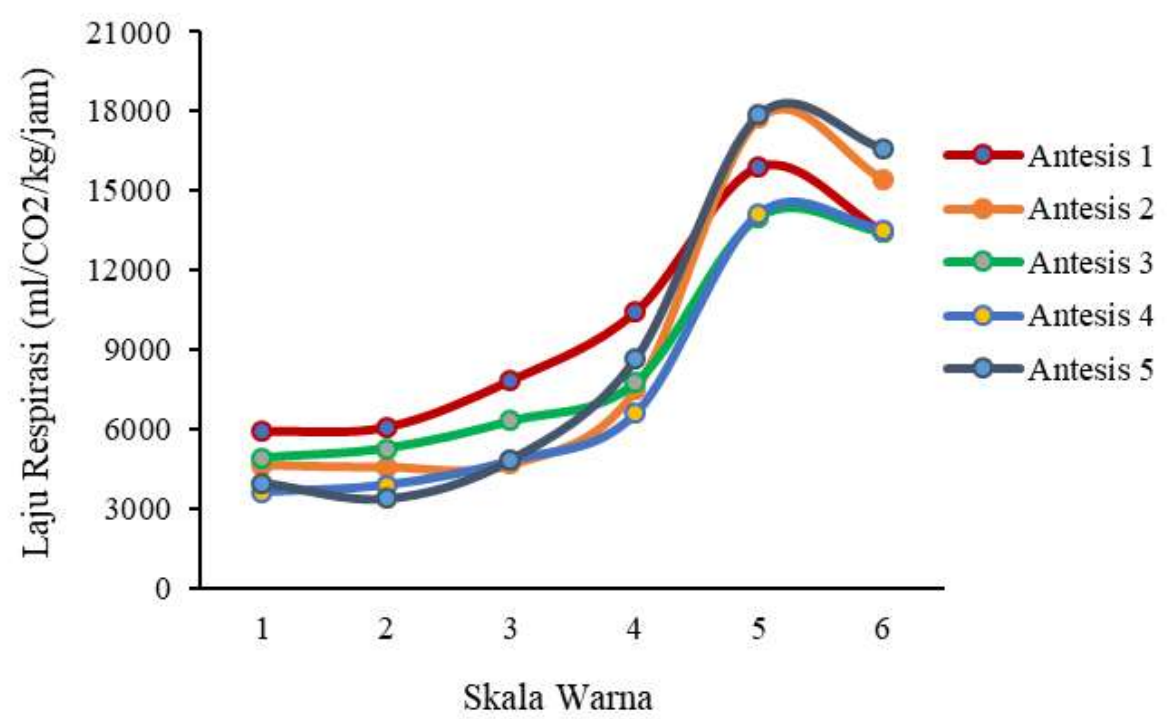

Gambar 1. Laju respirasi pisang Barangan selama proses pemeraman

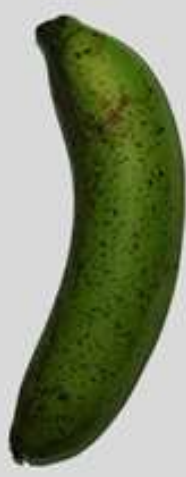

1

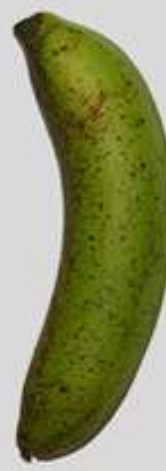

2

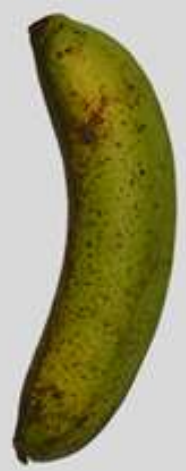

3

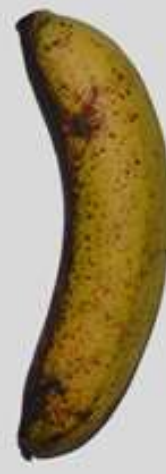

4

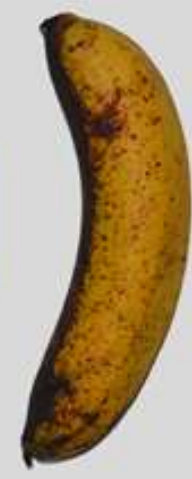

5

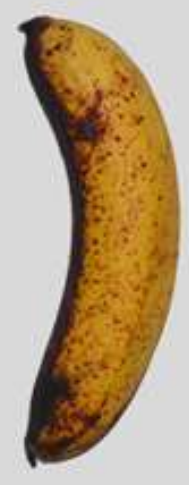

6

Gambar 2. Indeks skala warna kematangan buah pisang Barangan (1) hijau, (2) hijau dengan sedikit kuning, (3) hijau kekuningan, (4) kuning lebih dominan dari hijau, (5) kuning dengan ujung hijau dan (6) kuning penuh. 
Warna kulit buah mengalami perubahan selama proses pematangan dari warna hijau sampai berwarna kuning penuh. Perubahan warna kulit ini dibagi dalam 6 indeks skala warna yang menjadi indikator tingkat kematangan buah pisang. Perubahan warna kulit buah pisang Barangan disajikan pada Gambar 2.

Perubahan warna kulit ini disebabkan adanya degradasi klorofil selama pematangan buah. Menurut Mohapatra et al. (2010) selama pematangan buah pisang terjadi peningkatan produksi gas etilen serta peningkatan nilai warna kuning pada suhu $20{ }^{\circ} \mathrm{C}$. Degradasi klorofil ini menyebabkan kulit buah berubah menjadi kuning.

\section{Kualitas Fisik buah}

Perbedaan waktu antesis menunjukkan hasil tidak berpengaruh mempengaruhi susut bobot, kelunakan daging dan buah serta BDD. Pisang Barangan dipanen pada waktu antesis berbeda dengan satuan panas $1225^{\circ} \mathrm{C}$ hari tidak berpengaruh terhadap kualitas fisik buah. Susut bobot berkorelasi negatif terhadap umur simpan $(\mathrm{r}=-0.35)$, semakin besar susut bobot maka umur simpan semakin singkat. Ahmad et al. (2006) melaporkan bahwa penyusutan bobot mengakibatkan kehilangan air pada buah akibat respirasi dan transpirasi selama pemeraman sehingga berpengaruh terhadap daya simpan buah.
Kelunakan daging cenderung lebih besar dari pada kelunakan kulit. Kelunakan daging memiliki korelasi positif dengan umur simpan $(r=0.20)$, artinya semakin lama umur simpan maka kelunakan daging semakin tinggi. Menurut Gao et al. (2016) pelunakan buah berhubungan dengan proses konversi pati menjadi gula, pemecahan zat pektin dan pergerakan air dari kulit ke daging buah selama proses pematangan terjadi.

Buah mengalami susut bobot selama proses pemasakan akibat respirasi buah. Menurut Yachuan et al. (2007) susut bobot terjadi karena jaringan buah kehilangan air akibat proses transpirasi dan respirasi selama penyimpanan buah.

\section{Warna Kulit dan Daging Buah}

Waktu antesis berbeda menunjukkan hasil pengaruh nyata pada nilai $\mathrm{L}^{*}$ (lightness) dan $\mathrm{b}^{*}$ (yellowness) kulit dan daging buah pisang tetapi tidak mempengaruhi nilai a* (redness). Nilai L* yang tinggi menunjukkan tingkat kecerahan warna yang lebih cerah. Nilai $L^{*}$ pada warna kulit dan daging buah tertinggi pada antesis 1 (59.29) pada kulit dan (68.80) pada daging buah. Pada daging buah nilai $b^{*}$ tertinggi pada antesis 1 yaitu 30.55 (Tabel 4). Menurut Bugaud et al. (2007) faktor yang mempengaruhi warna buah adalah suhu harian dan curah hujan selama pertumbuhan buah pada tandan pisang.

Tabel 3. Kualitas fisik pisang Barangan pada lima waktu antesis

\begin{tabular}{cccccc}
\hline Waktu Antesis & $\begin{array}{c}\text { Umur } \\
\text { Simpan } \\
\text { (hari) }\end{array}$ & $\begin{array}{c}\text { Susut } \\
\text { Bobot } \\
(\%)\end{array}$ & $\begin{array}{c}\text { Kelunakan Daging } \\
\left(\mathrm{mm} \mathrm{g}^{-1} \text { detik }^{-1}\right)\end{array}$ & $\begin{array}{c}\text { Kelunakan } \\
\text { Kulit } \\
\left(\mathrm{mm} \mathrm{g}^{-1} \mathrm{detik}^{-1}\right)\end{array}$ & $\begin{array}{c}\text { Bagian Buah } \\
\text { dapat Dimakan } \\
(\%)\end{array}$ \\
\hline Antesis 1 & 16.8 & 15.28 & 0.016 & 0.006 & 68.60 \\
Antesis 2 & 16.2 & 15.28 & 0.016 & 0.006 & 68.86 \\
Antesis 3 & 17.0 & 14.97 & 0.016 & 0.004 & 70.09 \\
Antesis 4 & 17.2 & 16.68 & 0.017 & 0.004 & 67.91 \\
Antesis 5 & 16.6 & 15.38 & 0.016 & 0.005 & 70.39 \\
\hline
\end{tabular}

Tabel 4. Kecerahan warna kulit dan daging buah pisang Barangan pada lima waktu antesis menggunakan colorimeter

\begin{tabular}{clccccc}
\hline \multirow{2}{*}{ Waktu Antesis } & \multicolumn{3}{c}{ Warna Kulit Buah } & \multicolumn{3}{c}{ Warna Daging Buah } \\
\cline { 2 - 7 } & \multicolumn{1}{c}{$\mathrm{L}^{*}$} & $\mathrm{a}^{*}$ & $\mathrm{~b}^{*}$ & $\mathrm{~L}^{*}$ & $\mathrm{a}^{*}$ & $\mathrm{~b}^{*}$ \\
\hline Antesis 1 & $59.29 \mathrm{a}$ & 13.04 & $32.54 \mathrm{a}$ & $68.80 \mathrm{a}$ & 7.72 & $30.55 \mathrm{a}$ \\
Antesis 2 & $56.81 \mathrm{ab}$ & 13.80 & $33.25 \mathrm{a}$ & $67.67 \mathrm{ab}$ & 7.73 & $29.76 \mathrm{a}$ \\
Antesis 3 & $51.68 \mathrm{~b}$ & 11.76 & $26.33 \mathrm{~b}$ & $61.55 \mathrm{abc}$ & 6.70 & $25.06 \mathrm{~b}$ \\
Antesis 4 & $57.36 \mathrm{ab}$ & 11.43 & $33.35 \mathrm{a}$ & $60.84 \mathrm{bc}$ & 7.41 & $25.44 \mathrm{~b}$ \\
Antesis 5 & $56.69 \mathrm{ab}$ & 10.87 & $31.52 \mathrm{a}$ & $59.95 \mathrm{c}$ & 8.24 & $25.81 \mathrm{~b}$ \\
\hline
\end{tabular}

Keterangan: Angka-angka yang diikuti huruf yang sama pada kolom yang sama menunjukkan nilai yang tidak berbeda nyata berdasarkan uji lanjut BNJ pada taraf $5 \%$. 
Nilai a* mewakili warna merah dan $-\mathrm{a}^{*}$ mewakili warna hijau dimana selama proses pematangan terjadi penurunan warna hijau menjadi merah. Nilai $\mathrm{b}^{*}$ (kuning) memiliki nilai yang lebih besar dari pada nilai a* sehingga warna kuning pada kulit dan daging buah pisang lebih dominan dari pada warna merah. Menurut Soltani et al. (2011) perubahan warna buah pisang disebabkan oleh hilangnya klorofil dan munculnya pigmen lain seperti karotenoid yang membuat warna kuning dan merah pada buah. Perubahan warna juga terjadi pada daging buah yaitu dari keputih-putihan menjadi kekuningan.

\section{Kualitas Kimia Buah Pisang}

Hasil percobaan menunjukkan kandungan PTT tidak dipengaruhi oleh waktu antesis. Pisang Barangan yang dipanen dengan akumulasi satuan panas yang sama, kandungan PTT tidak dipengaruhi oleh waktu antesis.

Konsentrasi padatan terlarut mencerminkan konsentrasi gula dalam buah. Subedi dan Walash (2011) menyatakan selama pematangan, pati dirubah menjadi gula terlarut, pada proses ini beberapa komponen akan mengalami perubahan seperti warna kulit dan kelunakan daging.

Kandungan asam terlarut total (ATT) secara umum tidak dipengaruhi oleh waktu antesis. Dari lima waktu antesis, hanya antesis 4 yang menunjukkan perbedaan nyata dibandingkan dengan waktu antesis lainnya (Tabel 5). Tandan buah dari antesis 4 memiliki jumlah hari hujan yang tinggi yaitu 53 hari (Tabel 2). Menurut Etienne et al. (2014) faktorfaktor yang dapat mempengaruhi keasaman buah pisang diantaranya pemenuhan kebutuhan air, pemupukan dan suhu lingkungan. Keasaman buah dipengaruhi oleh konsentrasi asam organik dalam daging buah yang dihasilkan dari akumulasi air dan bahan kering. Menurut Dorey et al. (2016) selama periode pembungaan hingga panen faktor suhu dan curah hujan mempengaruhi kandungan ATT saat buah nanas dipanen.

Kandungan Vitamin $\mathrm{C}$ dalam buah pisang Barangan tidak dipengaruhi oleh waktu antesis (Tabel 5). Hal ini berarti pisang Barangan dipanen pada waktu antesis berbeda dengan akumulasi satuan panas $1225{ }^{\circ} \mathrm{C}$ hari memiliki kandungan vitamin $\mathrm{C}$ yang tidak berbeda. Menurut Fernando et al. (2014) bahwa kandungan asam askorbat (vitamin C) dan kadar gula meningkat seiring berjalannya proses pematangan dan mengalami penurunan ketika buah terlalu matang. Pada buah yang sudah mengalami penuaan (senescence) terjadi penurunan kondisi dan aktivitas metabolisme.

Kandungan proksimat pada pisang Barangan antesis 1 hingga antesis 5 memiliki kadar air $63.03 \%$, kadar abu $1.44 \%$, lemak $0.23 \%$, protein $1.07 \%$, serat kasar $0.22 \%$ dan karbohidrat $34.00 \%$ (Tabel 6).

Tabel 5. Kualitas kimia pisang Barangan pada lima waktu antesis

\begin{tabular}{cccc}
\hline Waktu Antesis & $\begin{array}{c}\text { PTT } \\
\left({ }^{0} \text { Brix }\right)\end{array}$ & $\begin{array}{c}\text { ATT } \\
(\%)\end{array}$ & $\begin{array}{c}\text { Vitamin C } \\
\left(\mathrm{mg} \mathrm{100}^{-1}\right)\end{array}$ \\
\hline Antesis 1 & 30.13 & $0.72 \mathrm{~b}$ & 66.88 \\
Antesis 2 & 29.35 & $0.72 \mathrm{~b}$ & 68.64 \\
Antesis 3 & 30.01 & $0.70 \mathrm{~b}$ & 63.36 \\
Antesis 4 & 29.63 & $0.90 \mathrm{a}$ & 62.77 \\
Antesis 5 & 30.03 & $0.77 \mathrm{~b}$ & 67.47 \\
\hline
\end{tabular}

Keterangan: Angka-angka yang diikuti huruf yang sama pada kolom yang sama menunjukkan nilai yang tidak berbeda nyata berdasarkan uji lanjut BNJ pada taraf 5\%.

Tabel 6. Kandungan proksimat pisang Barangan dari lima waktu antesis

\begin{tabular}{ccccccc}
\hline \multirow{2}{*}{ Waktu Antesis } & Kadar Air & Abu & Lemak & Protein & Serat Kasar & Karbohidrat \\
\cline { 2 - 7 } & & & & $\%$ & & \\
\hline Antesis 1 & 63.50 & 1.54 & 0.18 & 1.10 & 0.23 & 33.46 \\
Antesis 2 & 61.60 & 1.39 & 0.12 & 1.10 & 0.23 & 35.57 \\
Antesis 3 & 64.00 & 1.41 & 0.29 & 1.07 & 0.27 & 33.00 \\
Antesis 4 & 63.35 & 1.41 & 0.20 & 1.18 & 0.21 & 33.60 \\
Antesis 5 & 62.68 & 1.47 & 0.37 & 0.91 & 0.18 & 34.38 \\
\hline Rata-rata & 63.03 & 1.44 & 0.23 & 1.07 & 0.22 & 34.00 \\
\hline
\end{tabular}


Kandungan proksimat pisang barangan lebih tinggi dibandingkan pisang Cavendish dengan kadar abu $0.8 \%$, lemak $0.2 \%$, protein $1.1 \%$, karbohidrat $22.2 \%$ tetapi kadar air pisang Cavendish lebih tinggi yaitu $75 \%$ (Anyasi et al., 2013). Auta dan Kumurya (2015) melaporkan kandungan serat kasar pada buah pisang dalam jumlah besar mampu menurunkan kolesterol dan gula darah. Pisang Barangan memiliki karbohidrat lebih banyak dibandingkan pisang meja (Musa spp.). Pisang meja ini memiliki kandungan karbohidrat sebesar $21.8 \%$ (Ashokkumar et al., 2018).

\section{KESIMPULAN}

Akumulasi satuan panas $1234.50 \pm 2.76$ ${ }^{0} \mathrm{C}$ hari dapat digunakan sebagai kriteria panen pisang Barangan dengan umur panen 72-73 HSA dan umur simpan 16-17 hari. Waktu antesis yang berbeda mempengaruhi umur simpan, jumlah buah per sisir, bobot per sisir dan bobot per buah, kualitas fisik (susut bobot, bagian buah dapat dimakan, kelunakan kulit dan daging buah) dan kualitas kimia buah (padatan terlarut total, asam tertitrasi total, vitamin $\mathrm{C}$ dan proksimat).

\section{UCAPAN TERIMA KASIH}

Terima kasih penulis ucapkan kepada Lembaga Pengelola Dana Pendidikan (LPDP) sebagai sponsor yang telah membiayai percobaan ini pada tahun 2019 .

\section{DAFTAR PUSATAKA}

Abdurrohim, M.S., W.D. Widodo, K. Suketi. 2018. Heat unit establishment as harvest criteria on "Mas Kirana" banana at various times of anthesis. J Tropical Crop Science. 5(2):41-48.

Ahmad, S., M.A. Perviez, Z.A. Chatha, A.K. Thompson. 2006. Improvement of banana quality in relation to storage humidity, temperature and fruit length. Int. J. Agri. Bio. 8(3):1560-8530.
Anyasi, T.A., A.I.O. Jideani, G.R.A. Mchau. 2013. Functional properties and phostharvest utilization of commmercial and noncommercial banana cultivar. Comprehensive Reviews in Food Science and Food Safety. 12:509-522.

[AOAC] Association Official Agriculture Chemist. 1995. Official Methods of Analysis of Association Official Agriculture Chemist. Washington DC (US).

Ashokkumar, K, S. Elayabalan, V.G. Shobana, P. Sivakumar, M. Pandiya. 2018. Nutritional value of cultivars of Banana (Musa spp.) and its future prospects. Journal of Pharmacognosy and Phytochemistry. 7(3):2972-2977.

Auta, S.A. A.S. Kumurya. 2015. Comparative proximate, mineral elements and antinutrients composition between Musa sapientum (banana) and Musa paradisiaca (plantain) pulp flour. Sky J. Biochem Res. 4(4):25-30.

[BPS] Badan Pusat Statistik. 2019. Produksi tanaman buah-buahan pisang. https:// www.bps.go.id/site/resultTab. [5 Agustus 2019].

Bugaud, C., M.O. Daribo, C. Dubois. 2007. Climatic conditions affect the texture and colour of Cavendish bananas (Grande Naine cultivar). Scientia Horticulturae. 113:238-243.

Dorey, E., P. Founier, M. Lechaudel, P. Tixier. 2016. A statistical model to predict titratable acidity of pineapple during fruit developing period responding to climatic variables. Scientia Horticulturae. 2(10):19-24.

Dzomeku, B.M., J. Sarkordie-Addo, S.K. Darkey, R.K. Bam, J. Wuensche. 2016. Evaluating postharvest characteristics of Apantu (Local False Horn) plantain for harvest indices determination. Int. J. Plant Physiol Biochem. 8(1):1-6. 
Etienne, A., M. Genard, D. Bancel, S. Benoit, G. Lemire, C. Bugaud. 2014. Citrate and malate accumulation in banana fruit (Musa sp. AA) is highly affected by genotype and fruit age, but not by cultural practices. Sci Hort. 169:99-110.

Fernando, H.R.P., V. Srilaong, N. Pongprasert, P. Boonyaritthongchai, P. Jitareerat. 2014. Changes in antioxidant properties and chemical composition during ripening in banana variety 'Hom Thong' (AAA group) and 'Khai' (AA group). J. Food Research. 21(2):749-754.

Gao, H., S. Huang, T. Dong, Q. Yang, G. Yi. 2016. Analysis of resistant starch degradation in postharvest ripening of two banana cultivars: Focus on starch structure and amylases. Postharvest biology and technology. 199:1-8.

[Kementan] Kementerian Pertanian. 1995. Deskripsi pisang varietas Barangan. http://varitas.net/dbvarietas/deskripsi/33 65.pdf. [25 Oktober 2018].

Kheng, T.Y., P. Dhing, N.A.A Rahman. 2011. Determination of optimum harvest maturity and physico-chemical quality of Rastali banana (Musa AAB Rastali) during fruit ripening. J. Sci Food Agric. 92:171-17.

Mahopatra, D., S. Mishra, N. Sutar. 2010. Banana and it's by-product utilisation: An overview. J. Scientific and Industrial Reseach. 69:323-329.
Meena, R.S., R.S. Yadav, V.S. Meena. 2013. Heat unit efficiency of groundnut varieties in scattered planting with various fertility levels. The Bioscan. 8(4): 1189-1192.

Murtadha, A., E. Julianti, I. Suhaidi. 2012. Pengaruh jenis pemacu pematangan terhadap mutu buah pisang barangan (Musa parasidiaca L). J. Rekayasa Pangan dan Pertanian. 1(1):47-56.

Rahayu. M.D., W.D. Widodo, K. Suketi. 2014. Penentuan waktu panen pisang Raja Bulu berdasarkan evaluasi beberapa umur petik. J. Hort. Indonesia. 5(2):6572.

Soltani. M., R. Alimardani, M. Omid. 2011. Changes in physico-mechanical properties of banana fruit during ripening treatment. J. of American Science. 7(5):14-19.

Subedi, P.P., K.B. Walsh. 2011. Assessment of sugar and starch in intact banana and mango fruit by SWNIR spectroscopy. Postharvest Biology and Technology. 62: 235-245.

Widodo, W.D., K. Suketi, R. Rahardjo. 2019. Evaluasi kematangan pascapanen pisang Barangan untuk menentukan waktu panen terbaik berdasarkan akumulasi satuan panas. Bul. Agrohorti. 7(20):162171.

Yachuan, Z., Z. Liu, J.H. Han. 2007. Modeling Modified Atmosphere Packaging For Fruits and Vegetables. New York (US): CRC Press. 